\title{
Can executive equity incentives promote high-quality development of enterprises? _ Mediating effect based on innovation
}

\author{
Linya Cai ${ }^{1}$, Huawei $\mathrm{Luo}^{1}{ }^{*}$ \\ ${ }^{1}$ College of Management, Sichuan Agricultural University, 611130 Chengdu, Sichuan Province, China
}

\begin{abstract}
High quality is the direction of development, innovation drives high-quality development, and interest incentives drive innovation. Existing studies have shown that executive equity incentives can increase the financial performance of enterprises. Therefore, can executive equity incentives promote the high-quality development of enterprises, thereby improving the quality of industrial development? This paper takes China's knowledge-intensive enterprises as a sample from 2015 to 2019. On the basis of using the LP semiparametric estimation method to measure the total factor productivity of the enterprise, in accordance with the intermediary effect test procedure, the stepwise regression method is used to study the innovation-driven effect of the executive equity incentives on the quality of enterprise development. The study found that executive equity incentives have an inverted $U$-shaped impact on the high-quality development of companies, with $20 \%$ being the optimal ratio. There is a partial mediating effect in corporate innovation activities on this transmission path. Based on this, suggestions are made to share residual income with senior management and build a high-quality innovative production chain.
\end{abstract}

\section{Introduction}

"High-quality development" is the first statement put forward by the 19th National Congress of the Communist Party of China in 2017, indicating that China's economy has begun to shift from a stage of rapid growth to a stage of high-quality development. As the main force that promotes the development of the capital market and the improvement of economic quality, the importance of improve the quality of enterprise development is selfevident. The proposal of the "innovation-driven development" strategy provides a new feasible path for the improvement of the quality of enterprise development. As early as the report of the 18th National Congress of the Communist Party of China, the goal of "my country enters the ranks of innovative countries by 2020" was clearly stated. People are the core element of innovation, and knowledge-intensive enterprises with "people" as their important assets are the main force and leader of innovation. Therefore, taking knowledge-intensive enterprises as an observation point can better explore the role of people in innovation and innovation in highquality development. The knowledge-intensive enterprise Huawei has implemented six large-scale equity incentive plans, and $99 \%$ of the existing shares are held by the labor union committee of Huawei, which mobilizes people's enthusiasm to the maximum. It created the myth that growing from a small company with a registered capital of 20,000 yuan to No. 49 on the Fortune Global 500 list in 2020. The management style of the executives has an important influence on the innovation activities of the company. Can the implementation of equity incentives for the executives and sharing of residual income with them promote the high-quality development of the company? Does innovation play a role in this?

\section{Literature review}

Executive equity incentives have the possibility of affecting the development quality of enterprise. Some previous studies have affirmed the positive effect of equity incentives on the quality of enterprise development. They believe that even though there are problems of underinvestment or overinvestment, equity incentives can still promote the improvement of enterprise investment efficiency [1] and alleviate information asymmetry. Agency issues, thereby enhancing the value of the company and the interests of investors [2], and compared with companies that have not implemented equity incentives, companies implement equity incentives will attract more market attention, and the gap between the company's actual performance and market expectations is smaller [3]. However, some scholars also expressed doubts about the positive effects of executive equity incentives. Foreign scholars divide the motivations of equity incentives into two types. The first is to reduce agency costs, the second is to seek personal gains for executives. The management may set up a beneficial equity incentive plan to convey benefits or use some insider information for huge benefits [4]. Some domestic

\footnotetext{
Huawei Luo: 827634066@qq.com
} 
scholars believe that opportunistic behavior is implicit in the design of some equity incentive plans, and the performance appraisal indicators set are too loose to achieve the incentive effect $[5,6]$. After the share ratio of employees is greater than a certain ratio, the performance of the company will decline [7].

Existing research on the topic of executive equity incentives mainly focuses on the impact on corporate performance and its mechanism of action. Although these mechanisms of action may also affect the high-quality development of enterprises, they have not gone deep into the impact of executive equity incentives with the innovation-driven mechanism of China on the highquality development of enterprises. Therefore, on the basis of combing previous related researches, this article starts with knowledge-intensive companies that pay more attention to innovation, and empirically analyzes the innovation-driven effect of executive equity incentives on the quality of corporate development, with a view to provides reference for developing corporate equity incentive policies and improvement of quality.

\section{Theoretical analysis and research hypothesis}

Due to the unobservable performance of executives and the information asymmetry between shareholders and management, shareholders cannot evaluate the work of executives effectively, and they cannot control a series of damages to the company caused by the deviation of management's work goals from shareholders' interests. Senior management equity incentives allow management to share the residual income rights of the company with shareholders, which is conducive to improving the enthusiasm of management and promoting the convergence of the interests of management and shareholders, thereby improving the quality of corporate development. But this kind of beneficial effect does not always exist. Excessive incentives will lead to irrational behavior of management, build a personal empire for the realization of personal goals, and hinder the development of the company.

Innovation as a key to enhance the competitiveness of enterprises plays an important role in the influence path of executive equity incentives on the quality of enterprise development. Executive equity incentives will promote the convergence of the interests of management and shareholders, so that management have to increase R\&D investment and accelerate innovation output for the purpose of expanding the competitiveness of the company and enhancing the long-term value of the company. Thereby, exerting the effect of innovation-driven development, and have an impact on the quality of enterprise development. Therefore, this article proposes the following hypotheses:

H1: There is an inverted U-shaped relationship between executive equity incentives and the quality of corporate development.
$\mathrm{H} 2$ : Innovation play a part of the intermediary role in the impact of executive equity incentives on the quality of enterprise development.

\section{Research design}

Captions should be typed in 9-point Times. They should be centred above the tables and flush left beneath the figures.

\subsection{Model setting and variable definition}

In order to test the comprehensive impact of equity incentives on the high-quality development of enterprises, a benchmark regression model as shown in equation (1) is constructed:

$t f p \_l p_{i t}=\alpha_{0}+\alpha_{1}$ incentive $_{i t}+\alpha_{2}$ incentive_ $2_{i t}+\alpha_{3} \ln \_$size ${ }_{i t}$

$+\alpha_{4}$ age $_{i t}+\alpha_{5}$ age_ $2_{i t}+\alpha_{6}$ roa $_{i t}+\alpha_{7}$ solvency $_{i t}+\alpha_{8}$ largest $_{i t}+\alpha_{9} i n$ director $_{i t}+\alpha_{10} \sum$ year $_{t}+\pi_{i}+\mu_{t}+\varepsilon_{i t}$

$\alpha$ represents the regression coefficient, $\pi$ and $\mu$ represent the individual effect and time effect, respectively, $\varepsilon$ is the random disturbance term, $i$ represents the company numbered $i$, and $t$ represents time.

In order to further investigate whether executive equity incentives will have an indirect impact on the quality of development by influencing corporate innovation activities, this article adopts the intermediary effect test procedure recommended by Wen Zhonglin and Ye Baojuan (2014), and use the causal stepwise regression method to conduct research [8]. Therefore, a mediating effect test model as shown in equations (2)-(5) is constructed:

$R \& D_{i t}=\beta_{0}+\beta_{1}$ incentive $_{i t}+\beta_{2}$ incentive_ $2_{i t}+\beta_{3}$ ln_size sit $_{i t}$ $+\beta_{4}$ age $e_{i t}+\beta_{5}$ age_ $2_{i t}+\beta_{6}$ roa $_{i t}+\beta_{7 \text { Solvency }}+\beta_{8}$ largest $_{i t}+\beta_{\text {gind }}$ irector $_{i t}+\beta_{10} \sum$ year $_{t}+\pi_{i}+\mu_{t}+\varepsilon_{i t}$

$O P_{i t}=\gamma_{0}+\gamma_{1}$ incentive $_{i t}+\gamma_{2}$ incentive_ $2_{i t}+\gamma_{3} l n \_$size $e_{i t}$ $+\gamma_{4}$ age ${ }_{i t}+\gamma_{5}$ age $2_{i t}+\gamma_{6}$ roa $_{i t}+\gamma_{7}$ Solvency $_{i t}+\gamma_{8}$ largest ${ }_{i t}+\gamma_{9}$ indir ector $_{i t}+\gamma_{10} \sum$ year $_{t}+\pi_{i}+\mu_{t}+\varepsilon_{i t}$ $t f p \_l p_{i t}=\delta_{0}+\delta_{1} l n \_s i z e_{i t}+\delta_{2} a g e_{i t}+\delta_{3}$ age_2 $2_{i t}$ $+\delta_{4}$ roa $_{i t}+\delta_{5}$ Solvency $_{i t}+\delta_{6}$ largest $_{i t}+\delta_{7}$ indirector $_{i t}+\delta_{8} R \& D_{i t+}$ $\delta_{9} R \& D \_2_{i t}+\delta_{10} O P_{i t}+\delta_{11} O P \_2_{i t}+\delta_{12} \sum$ year $_{t}+\pi_{i}+\mu_{t}+\varepsilon_{i t}$ (4)

$t f p \_l p_{i t}=\theta_{0}+\theta_{1}$ incentive $_{i t}+\theta_{2}$ incentive_ $2_{i t}+\theta_{3}$ ln_size $_{i t}$ $+\theta_{4}$ age $e_{i t}+\theta_{5}$ age $2_{i t}+\theta_{6}$ roa $_{i t}+\theta_{7}$ Solvency $_{i t}+\theta_{8}$ largest $_{i t}+\theta_{9}$ ind irector $_{i t}+\theta_{10} R \& D_{i t}+\theta_{11} R \& D \_2_{i t}+\theta_{12} O P_{i t}+\theta_{13} O P \_2_{i t}+\theta_{14}$ $\sum$ year $_{t}+\pi_{i}+\mu_{t}+\varepsilon_{i t}$

In above formula, in order to examine the nonlinear relationship between the variables, the quadratic terms of the main variables are added to the model. $\beta, \gamma, \delta, \theta$ represent regression coefficients, $\pi$ and $\mu$ represent individual effects and time effects, respectively, $\varepsilon$ is a random disturbance term, $i$ represents the enterprise numbered $i$, and $t$ represents time. The specific definitions of variables are shown in Table 1. 
Table 1. Table of the variable definition

\begin{tabular}{|c|c|c|c|}
\hline Types & Name & Symbol & definition \\
\hline Explained variable & Enterprise development quality & tfp_lp & $\begin{array}{l}\text { Using LP semi-parametric estimation } \\
\text { method to get }\end{array}$ \\
\hline \multirow[t]{2}{*}{ Explanatory variables } & \multirow[t]{2}{*}{ Executive shareholding ratio } & incentive & $\begin{array}{l}\text { Number of shares held by } \\
\text { executives/total number of shares }\end{array}$ \\
\hline & & incentive_2 & incentive*incentive \\
\hline \multirow{4}{*}{ Mediating variable } & \multirow{2}{*}{ Innovation investment } & R\&D & R\&D expenses/operating income \\
\hline & & $\mathrm{R} \& \mathrm{D} \_2$ & $\mathrm{R} \& \mathrm{D} * \mathrm{R} \& \mathrm{D}$ \\
\hline & \multirow{2}{*}{ Innovation output } & $\mathrm{OP}$ & $\ln ($ Total number of patents +1$)$ \\
\hline & & OP_2 & $\mathrm{OP} * \mathrm{OP}$ \\
\hline \multirow{8}{*}{ Control variable } & Enterprise size & ln_size & Natural logarithm of total assets \\
\hline & \multirow[t]{2}{*}{ Business age } & age & $\begin{array}{l}\text { Year of calculation period minus year } \\
\text { of establishment of the company }\end{array}$ \\
\hline & & age_2 & age*age \\
\hline & Roa & roa & $\begin{array}{l}\text { Profit before interest and tax/average } \\
\text { total assets }\end{array}$ \\
\hline & Solvency & solvency & $\begin{array}{l}\text { Net cash flow from operating } \\
\text { activities/total liabilities }\end{array}$ \\
\hline & $\begin{array}{l}\text { The largest shareholder's } \\
\text { shareholding ratio }\end{array}$ & largest & $\begin{array}{l}\text { Number of shares held by the largest } \\
\text { shareholder/total number of shares }\end{array}$ \\
\hline & $\begin{array}{l}\text { Proportion of independent } \\
\text { directors }\end{array}$ & indirector & $\begin{array}{l}\text { Number of independent } \\
\text { directors/directors }\end{array}$ \\
\hline & Year & year & \\
\hline
\end{tabular}

\subsection{Sample selection and data sources}

Because knowledge-intensive enterprises have the characteristics of large investment in innovation, high knowledge and technology intensiveness, and obvious spillover effects, this article restricts the research objects to knowledge-intensive industries. Up to December 31, 2019, a total of 498 listed companies have been classified as knowledge-intensive industries; 173 companies have been established for less than five years have been excluded; and 5 companies have been excluded from companies with a large amount of missing information. Finally, the panel data of 320 listed companies in knowledge-intensive industries during the five-year period from 2015 to 2019 were selected as the research samples. The data in this article are mainly derived from the CSMAR database and Juchao Information Network. Data processing is used Excel2017 and Stata14.0 software.

\section{Empirical analysis}

\subsection{Descriptive statistics of main variables}

Table 2 shows the descriptive statistical results of the main variables. It can be seen from Table 2 that the average total factor productivity measured by the LP method of the sample companies is 17.40, and the standard deviation is 1.2 , indicating that the gap in total factor productivity among enterprises in knowledgeintensive industries is small, the minimum shareholding ratio of executives is 0 and the maximum value is 0.67 , indicating that there is a large gap in the implementation of executive equity incentives among the sample companies, and the average value is 0.08 , it shows that most executives hold a low proportion of shares; the average value of innovation input is 0.06 , and the standard deviation is 0.08 , it shows that the R\&D investment level of the sample enterprises is relatively low, and the gap is small; the minimum value of innovation output is 0 , the maximum value is 9.11 , and the average value is 0.29 , it shows that the R\&D output level of the sample enterprises is low, but the gap is large. The distribution of the descriptive statistics of other variables is reasonable and similar to the existing research, so we won't repeat them here. 
Table 2. Descriptive statistics of main variables

\begin{tabular}{|l|l|l|l|l|l|}
\hline \multicolumn{1}{|c|}{ variable } & \multicolumn{1}{|c|}{$\mathbf{N}$} & \multicolumn{1}{|c|}{ Mean } & $\begin{array}{c}\text { Standard } \\
\text { deviation }\end{array}$ & \multicolumn{1}{|c|}{ min } & \multicolumn{1}{|c|}{$\mathbf{m a x}$} \\
\hline tfp_lp & 1,600 & 17.4048 & 1.2082 & 14.3738 & 21.6042 \\
\hline incentive & 1,600 & 0.0885 & 0.1412 & 0 & 0.6717 \\
\hline R\&D & 1,600 & 0.0655 & 0.0800 & 0 & 0.5749 \\
\hline OP & 1,600 & 0.2935 & 0.9934 & 0 & 9.1175 \\
\hline ln_size & 1,600 & 22.8560 & 2.2330 & 18.4908 & 31.0359 \\
\hline age & 1,600 & 18.2469 & 5.5962 & 6 & 38 \\
\hline roa & 1,600 & 0.0547 & 0.1812 & -2.5491 & 1.6150 \\
\hline solvency & 1,600 & 0.1199 & 0.3785 & -4.0974 & 2.6221 \\
\hline largest & 1,600 & 0.2874 & 0.1358 & 0.0355 & 0.7735 \\
\hline indirector & 1,600 & 0.3799 & 0.0551 & 0.1667 & 0.6667 \\
\hline
\end{tabular}

\subsection{Analysis of regression results.}

In order to avoid the problem of multicollinearity, this article calculates the correlation coefficient between the variables before regressing the panel data. The results are shown that the correlation coefficients between the variables are small. Therefore, it can be preliminarily determined that the collinearity of each variable in the equation is weak. Meanwhile, the average VIF value of the sample OLS regression is 1.25 , which is much less than 10 , it is further verified that there is no multicollinearity among the variables. In addition, the correlation between each variable and total factor productivity is more significant, indicating that the model setting is reasonable.

The regression results of the samples are shown in Table 4. First of all, in the regression results of all models, executive equity incentives have It shows that equity incentive is an important factor affecting the development quality and innovation activities of enterprises. Meanwhile, the regression coefficients of the first term are significantly positive, and the coefficients of the second term are significantly negative, that is showing an inverted U-shaped impact. Hypothesis (1) has been verified. Among them, the regression results of model (1) can be calculated that the executive equity incentive value at the peak of the inverted U-shaped curve is 19.55 percent, that is, when the shareholding ratio of senior executives is $19.55 \%$, the company's total factor productivity is the highest. Secondly, it examines the influence of the intermediary variable on total factor productivity, from the regression results of model (4), it can be seen that whether it is innovation input or innovation output, the coefficient of the first term is significantly negative, and the coefficient of the second term is significantly positive, it shows that enterprise innovation activities and enterprise development quality have a U-shaped impact. Finally, the model (5) is obtained by adding innovation input and innovation output as intermediary variables into the model of the influence of executive equity incentive on the total factor productivity of the explained variable. In model (5), the impact of executive equity incentives on total factor productivity still presents an inverted $U$ shape and the test results are significant, further compare model (1) and model (5) for analysis, in terms of fit, when added as an intermediary variable, the degree of fit has improved to a certain extent. At the regression coefficient, the absolute values of the regression coefficients of the primary and secondary terms of executive equity incentives are reduced. Combined with the three-step principle of the intermediary effect test, it can be seen that innovation plays a part of the intermediary role in the inverted U-shaped impact of executive equity incentives on the quality of enterprise development. Hypothesis (2) has been verified.

Table 3. Sample regression results

\begin{tabular}{|c|c|c|c|c|c|}
\hline & $(1)$ & $(2)$ & $(3)$ & $(4)$ & $(5)$ \\
\hline & tfp_lp & $\mathbf{R \& D}$ & $\mathbf{O P}$ & $\mathbf{t f p \_ l p}$ & tfp_lp \\
\hline incentive & $1.728^{* * *}$ & $0.056^{*}$ & $1.992^{* * *}$ & & $1.305^{* * *}$ \\
\hline & $(4.04)$ & $(1.86)$ & $(2.88)$ & & $(3.84)$ \\
\hline incentive_2 & $-4.419^{* * *}$ & $-0.153^{* *}$ & $-3.340^{* *}$ & & $-2.748^{* * *}$ \\
\hline & $(-4.84)$ & $(-2.49)$ & $(-2.30)$ & & $(-3.91)$ \\
\hline In_size & $0.439 * * *$ & 0.003 & -0.026 & $0.437^{* * *}$ & $0.436^{* * *}$ \\
\hline & $(43.67)$ & $(1.56)$ & $(-1.36)$ & $(29.93)$ & $(29.84)$ \\
\hline age & 0.026 & -0.001 & $-0.068^{* *}$ & $0.099^{* * *}$ & $0.103^{* * *}$ \\
\hline & $(1.54)$ & $(-0.57)$ & $(-2.22)$ & $(5.72)$ & $(5.93)$ \\
\hline age_2 & -0.001 & 0.000 & $0.001 *$ & $-0.002 * * *$ & $-0.002^{* * *}$ \\
\hline & $(-1.49)$ & $(1.19)$ & $(1.82)$ & $(-4.35)$ & $(-4.54)$ \\
\hline roa & 0.053 & $-0.016^{* * *}$ & -0.044 & 0.047 & 0.042 \\
\hline & $(0.51)$ & $(-3.68)$ & $(-0.34)$ & $(0.89)$ & $(0.81)$ \\
\hline solvency & 0.046 & $-0.008^{* * *}$ & 0.094 & -0.008 & -0.012 \\
\hline & $(0.93)$ & $(-3.58)$ & $(1.42)$ & $(-0.29)$ & $(-0.41)$ \\
\hline
\end{tabular}




\begin{tabular}{|c|c|c|c|c|c|}
\hline largest & $1.095^{* * *}$ & $-0.030^{*}$ & 0.357 & $0.358^{* *}$ & $0.511^{* * *}$ \\
\hline & $(7.19)$ & $(-1.65)$ & $(1.27)$ & $(2.09)$ & $(2.86)$ \\
\hline indirector & 0.001 & 0.014 & $-1.507^{* * *}$ & 0.145 & 0.163 \\
\hline & $(0.00)$ & $(0.66)$ & $(-2.88)$ & $(0.58)$ & $(0.66)$ \\
\hline R\&D & & & & $-3.500^{* * *}$ & $-3.649^{* * *}$ \\
\hline & & & & $(-6.48)$ & $(-6.77)$ \\
\hline R\&D_2 & & & & $4.496^{* * *}$ & $4.750^{* * *}$ \\
\hline & & & & $(3.25)$ & $(3.44)$ \\
\hline OP & & & & $-0.056^{* *}$ & $-0.060^{* *}$ \\
\hline & & & & $(-2.27)$ & $(-2.43)$ \\
\hline OP_2 & & & & $0.009^{*}$ & $0.010^{* *}$ \\
\hline & & & & $(1.93)$ & $(2.07)$ \\
\hline Cons & $6.817^{* * *}$ & 0.009 & $1.969^{* * *}$ & $6.382^{* * *}$ & $6.286^{* * *}$ \\
\hline & $(20.93)$ & $(0.20)$ & $(3.35)$ & $(16.84)$ & $(16.44)$ \\
\hline $\mathbf{N}$ & 1600 & 1600 & 1600 & 1600 & 1600 \\
\hline R2 & 0.642 & 0.053 & 0.037 & 0.657 & 0.663 \\
\hline
\end{tabular}

Note: $* * * \operatorname{Sig}<0.01, * * \operatorname{Sig}<0.05, * \operatorname{Sig}<0.1$, value of $\mathrm{t}$ in parentheses.

\subsection{Robustness test}

Executive equity incentives are conducive to promoting management to improve work efficiency, so as to promote the improvement of the quality of enterprise development. However, the improvement of the quality of enterprise development may also make the shareholders as clients increase the incentive for executives, this may cause endogenous problems. To further test whether endogeneity will affect the research conclusions, this article adopts the one-period lag of the explanatory variable for regression. The primary term of the explanatory variable lagging one period in the regression results is still significantly positive at the $1 \%$ level. Meanwhile, the quadratic term of the explanatory variable lagging one period is still significantly negative at the $1 \%$ level, and it further verifies the inverted U-shaped relationship between executive equity incentive and enterprise development quality.

\section{Conclusion and Enlightenment}

This paper takes listed companies in knowledge-intensive industries in China from 2015 to 2019 as samples. The LP semiparametric estimation method is used to measure the total factor productivity of enterprises to represent the quality of enterprise development, and builds an intermediary effect analysis model to examines the relationship among executive equity incentive, enterprise innovation and enterprise development quality. The conclusion is as follows:

First, from the perspective of the total effect, the impact of executive equity incentives on the quality of enterprise development presents an inverted U-shaped relationship, and the quality of corporate development is the highest when the shareholding ratio of executives is about 19.55 percent. On the one hand, appropriate equity incentives can stimulate the enthusiasm of the management, so that the agent problem caused by information asymmetry is alleviated, and then promote the improvement of the quality of enterprise development. On the other hand, excessive incentives can easily lead to management's behavior of building personal empire. thereby leading to a decline in the quality of enterprise development.

Second, innovation plays a part of the intermediary role in the inverted U-shaped impact of executive equity incentives on the quality of enterprise development. Above all, executive equity incentives will have an inverted U-shaped impact on innovation, that is, appropriate incentives can enhance executives' attention to innovation, however, too high shareholding ratio will make executives tend to avoid high-risk innovation activities in order to ensure the stability of residual income. Next, innovation will have a U-shaped impact on the quality of enterprise development, the uncertainty of the market prospects in the early stage of R\&D has an adverse effect on the quality of development. However, with the continuous growth of R\&D investment scale and innovation output, new enterprises Competitiveness is formed, so as to promote the steady improvement of development quality. In summary, the influence of executive equity incentive on the quality of enterprise development is partly exerted through innovation-driven development effect.

2021 is the year of acceptance of whether China can successfully enter the ranks of innovative countries. Continuously motivating enterprises to carry out innovation is of great significance for realizing the highquality development of Chinese enterprises and promoting the upgrading of industries. Therefore, this article proposes the following suggestions:

First, companies share residual income with executives. The previous article confirms the interval incentive effect of executive equity incentives on the high-quality development of knowledge-intensive enterprises. So we can refer to the conclusions of this article and use $19.55 \%$ as a starting point to find an incentive ratio suitable for the enterprise, so that the important asset of "people" can exert its due effect. And then promote the steady improvement of enterprise development quality.

Second, companies build a high-quality innovative production chain. Companies must focus on long-term development goals, increase input and output in 
innovation, promote the formation of innovation investment and transform it into innovation results, and transform innovation achievements into corporate competitiveness, ultimately promote the development of a high-quality innovative production chain that continuously improves the quality of the enterprise. so that it is conducive to industrial development.

\section{References}

1. C.J. Lv, H.P. Zhang. The Influence of Equity Incentive Plan on Corporate Investment Behavior, J. MW, 118-126 (2011)

2. H.W. Zhao. Equity Incentive, Corporate Governance and Enterprise Performance -- Empirical Evidence Based on Chinese Listed Companies, J. MR, 151-159 (2016)

3. Y.Q. Chu, Y.T. Cang and Y.Y. Chu, Equity Incentive, Market Concern and Market Expectation Realization, J. JSUFE, 81-95 (2020)

4. Erik Lie. On the Timing of CEO Stock Option Awards, 802-812 (2005)

5. Y.H. Wu, S. N. Wu, Executive compensation: Motivation or self-interest? -- Evidence from Chinese Listed Companies, J. AR, 40-48 (2010)

6. H.P. Zhang, C.J. Lv. Equity Incentive and Accounting Policy Choice of Listed Companies: Analysis Based on Asset Impairment Accounting, J. JFE, 60-70 (2011)

7. H.J. Fan, Z.H. Chu. Inverted U-shaped Influence of Equity Incentive on Corporate Performance, J. REM, 5-11 (2013)

8. Z.L. Wen, B.J. Ye. Mediating effect analysis: Methodology and Model Development, J. APS, 731745 (2014) 